\title{
Knowledge of young women concerning the impact of natural feeding on the growth and state of health of a baby
}

\author{
Alina Trojanowska', Magdalena Brodowicz-Król', Paulina Trojanowska² \\ ${ }^{1}$ Chair and Department of Paediatric Nursing, Faculty of Health Sciences, Medical University, Lublin, Poland \\ ${ }^{2}$ The I Faculty of Medicine with Dentistry Division, Medical University of Lublin, Poland \\ Trojanowska A, Brodowicz M. Knowledge of young women concerning the impact of natural feeding on the growth and state of health of \\ a baby. Ann Agric Environ Med. 2017; 24(3): 484-488. doi: 10.5604/12321966.1232772
}

\section{Abstract}

Introduction. Proper nutrition in childhood has a huge significance for the optimal physical and psychical growth and good state of health of a baby. Natural feeding is admittedly the healthiest method of feeding infants. In spite of increased knowledge about the short and long-term benefits of feeding babies with human milk, the percentage of infants nourished only by breastfeeding is still too low. Knowledge about the health benefits of breast milk should be spread among young women.

Objective. The aim of the study was to attempt to discover how much knowledge young women have about the impact of natural feeding on the growth and state of health of a baby, as well as estimating the need for education in this area. Materials and method. Questionnaire study conducted in 2013 among 155 young women (average age $25.43 \pm 5.98$ years) in Poland and in Belgium.

Results. Own studies show that natural feeding still needs promotion and support. Knowledge about this among respondents varied and was incomplete. Often, they did not know all the benefits of natural feeding. The majority of respondents were aware that breastfeeding influenced the growth and health of the baby, but they did not have full knowledge about it. The respondents also did not have sufficient knowledge about the advantages of natural feeding in subsequent adult life. Only a small percentage of respondents (15\%) had good knowledge about the benefits of breastfeeding. A higher level of knowledge occurred among women living in Poland who were older, better educated, lived in cities, and had breastfed earlier.

Conclusions. A quite varied and not too high level of knowledge among young women about the benefits of natural feeding was observed, which points to the necessity of intensification of educational activities among them in this area.

\section{Key words}

natural feeding, young women, knowledge

\section{INTRODUCTION}

Proper nutrition in childhood has a huge impact for the optimal physical and psychical growth of a child due to the dynamics of changes taking place in the organism $[1,2,3$, $4,5,6]$. Infancy is critical for the development of organs and tissues as the nutrition method can programme the system's metabolism by influencing the activity of enzymes, endocrinology or immune system. Therefore, the quality of nutrition in this period could have impact on many physiological and pathological processes, conditioning the state of health, both in childhood and in mature age. Civilization diseases, such as atherosclerosis, hypertension, diabetes, or obesity, constitute to a bigger and bigger problem in developed societies. Hence, the meaning of proper nutrition in the earliest life period as a protection factor should be particularly emphasized $[7,8,9]$.

The most natural, easily accessible, cheapest, and at the same time, the best method of feeding a child from birth is feeding with human milk. Its optimal composition, balanced with its quantity and quality, best fits the requirements of the growing organism. The benefits of natural feeding have been confirmed in numerous studies $[10,11,12,13]$.

Address for correspondence: Alina Trojanowska, Gębali 6, 20-093 Lublin, Poland Tel. 724863125

E-mail: trojanowska-a@wp.pl

Received: 24 January 2014; accepted: 17 December 2014; first published: February 2017
In spite of increased knowledge about the short and longterm benefits resulting from feeding babies with human milk, the percentage of infants nourished only by breastfeeding is still too low. In the USA, in studies of 1,160 mothers, only $24 \%$ breastfed in the $6^{\text {th }}$ month of a baby's life. In European countries, the percentage is slightly higher (ca. 34-36\% according to different studies), but is also not too high. This is undoubtedly related to the intensive advertising of products replacing breast milk $[14,15,16,17]$.

The woman prepares herself for breastfeeding long before pregnancy by creating the correct attitude towards natural feeding. Knowledge about natural feeding and readiness to gain this knowledge has an impact $[14,15,18,19]$. Knowledge about the health benefits of a woman's milk should be spread among young women. The subject of assessment of women's knowledge about the benefits of natural feeding is not popularized; therefore, the study was undertaken to counteract the ignorance that occurs.

\section{OBJECTIVE}

The aim of the study was to attempt to discover the extent of knowledge of young women about the impact of natural feeding on the growth and state of health of a baby, as well as to estimate the need for the education in this area. 


\section{MATERIALS AND METHOD}

The method of a diagnostic survey was used in 2013 among 155 young women in Poland and Belgium. As the research tool, an own questionnaire was used, especially constructed for this purpose. The gathered material was statistically analysed using the Statistica 9.1. programme. Significance of differences between studied characteristics was tested by: $\chi^{2}$, U Mann-Whitney and Kruskal-Wallis. Dependencies analysis was performed with the use of Spearman's correlation coefficient. Significance level was accepted at $\mathrm{p}<0.05$.

\section{RESULTS}

The respondents were 58.1\% Polish and $41.9 \%$ Belgian women, aged $18-46$ years (average age $25.43 \pm 5.98$ ), of whom $63.2 \%$ were single and $36.8 \%$ were married. $51.6 \%$ lived in the countryside and $48.4 \%$ in cities. The group was also differentiated in terms of education: $47.7 \%$ of the women had higher education, $38.1 \%$ secondary, $7.7 \%$ vocational, and $6.5 \%$ primary education. More than a half of the respondents worked (52.6\%), 43.2\% were still at different schools, and $5.2 \%$ had no job. The majority of respondents $(67.7 \%)$ did not have children, and the rest $-32.3 \%$, had $1-4$ children. Among women having children, $63.0 \%$ were breastfeeding them, and $37.0 \%$ were not. The length of breastfeeding in the studied group varied from 1-18 months, and most often (20\%) the answer was given as 2 months. The majority of respondents $(69.0 \%)$ declared that they would breastfeed their child, $20.6 \%$ did not want to breastfeed, while $10.4 \%$ did not know whether they would pursue this method of nutrition. The will to breastfeeding was declared more often by the Polish (82.2\%) than by the Belgian women $(50.8 \%$ : $\mathrm{p}=0,0000)$.

Analysis of 10 questionnaire questions revealed the knowledge young women have about natural feeding. For assessment of the level of knowledge in relation to basic issues regarding natural feeding, questions about different aspects of the impact on the baby were included. For each correct answer, the respondent received 1 point. When the answer was partly correct, she scored 0.5 point, and received 0 points for an incorrect response. The maximum score was 10 points. The average assessment of knowledge level of respondents was: $5.2 \pm 1.7$ points for Polish and 4.4 $\pm 1,5$ points for Belgian women. The minimum score was 1 point and the maximum -8.5 points. For the purpose of this study, and taking into account suggestions by Niemierko [20], the following criteria of knowledge about natural feeding assessment were adopted: 0-4 points - lack of knowledge, 5-6 points - incomplete knowledge, $7-10$ points - sufficient knowledge. The study showed that just over a half of the women $(55.5 \%)$ had incomplete knowledge in this area, almost $1 / 3$ (29.7\%) had a lack of knowledge, and only $14.9 \%$ have sufficient knowledge about natural feeding. The Polish women definitely had a higher level of knowledge than the Belgian women ( $p=0.001)$ (Fig. 1; Tab. 1).

When asked about the best method of feeding their babies, the majority of respondents (72.9\%) answered that it was mother's milk. Significantly more Polish (86.7\%) than Belgian women (53.8\%) thought so ( $\mathrm{p}=0,0002)$. The remaining $20.7 \%$ indicated mixed nutrition (mother's and artificial milk), 3.2\% indicated artificial feeding and 3.2\% had no opinion.

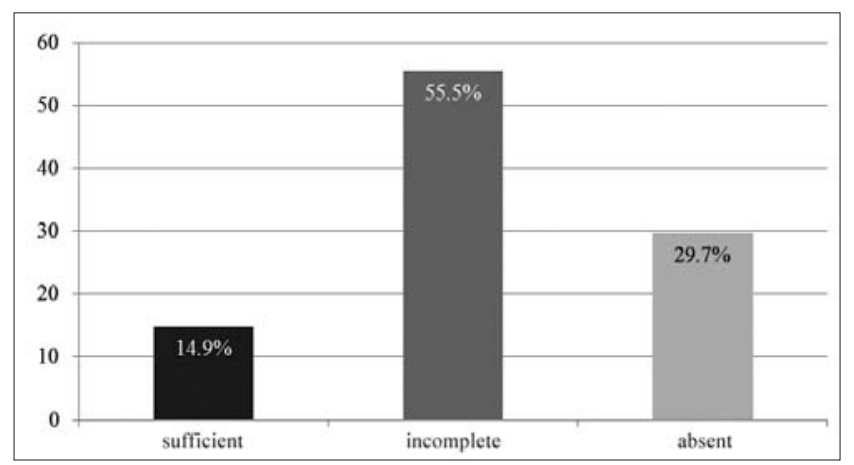

Figure 1. Level of knowledge on natural feeding among respondents

Table 1. Comparison of level of knowledge on natural feeding among respondents from Poland and Belgium

\begin{tabular}{llcccccc}
\hline \multirow{2}{*}{ Nationality } & High & Average & Median & Minimum & Maximum & $\begin{array}{c}\text { Standard } \\
\text { deviation }\end{array}$ \\
\hline \multirow{2}{*}{ Poland } & points & 90 & 5.2 & 5.1 & 1.0 & 8.5 & 1.7 \\
\cline { 2 - 8 } & $\%$ points & 90 & 52.3 & 51.2 & 10.0 & 85.0 & 17.2 \\
\hline \multirow{2}{*}{ Belgium } & points & 65 & 4.4 & 4.2 & 1.5 & 7.3 & 1.5 \\
\cline { 2 - 8 } & $\%$ points & 65 & 43.6 & 42.5 & 15.0 & 73.3 & 14.9 \\
\hline Statistical Analysis & $\mathrm{Z}=3.176905 ; \mathrm{p}=0.001489$ & & &
\end{tabular}

Almost half of the respondents (48.4\%) correctly gave the optimal length of breastfeeding only with breast milk (6 months), $8.4 \%$ said it was 3 months, $12.9 \%$ - 9 months, $20.6 \%-12$ months, and $9.7 \%$ had no knowledge in this area. Polish women had better knowledge than Belgian women $(\mathrm{p}=0,003)$.

For the question about which type of mother's milk (colostrum, transitional milk or mature milk) had the most immune cells, many respondents (65.9\%) answered correctly - colostrum, $21.9 \%$ - mature milk, and only $19.2 \%$ answered transitional milk. In this area, the Belgian women had greater knowledge than their Polish counterparts $(\mathrm{p}=0.010)$.

The majority of women (unfortunately not all) stated that breastfeeding had a positive impact on the infant. Polish

Table 2. Impact of natural feeding on a baby according to respondents of both nationalities.

\begin{tabular}{|c|c|c|c|c|c|}
\hline \multirow{2}{*}{$\begin{array}{l}\text { Impact of breastfeeding on } \\
\text { a baby }\end{array}$} & \multicolumn{2}{|c|}{ Poland } & \multicolumn{2}{|c|}{ Belgium } & \multirow{2}{*}{ Statistical analysis } \\
\hline & $\mathrm{n}$ & $\% *$ & $\mathrm{~N}$ & $\% *$ & \\
\hline $\begin{array}{l}\text { Promotes development of } \\
\text { emotional bond with mother }\end{array}$ & 85 & 94.44 & 54 & 83.08 & $\begin{array}{c}x^{2} \text { Yatesa }=4,112035 \\
p=0,04258\end{array}$ \\
\hline Fulfills the safety Reed? & 77 & 85.56 & 33 & 50.77 & $\begin{array}{c}\mathrm{X}^{2} \text { Yatesa }=20,51040 \\
\mathrm{p}=0,00001\end{array}$ \\
\hline Protects child from stress & 50 & 55.56 & 28 & 43.08 & $\begin{array}{c}x^{2} \text { Yatesa }=1,878242 \\
p=0,17054\end{array}$ \\
\hline $\begin{array}{l}\text { It does not differ from artificial } \\
\text { milk }\end{array}$ & 1 & 1.11 & 6 & 9.23 & $\begin{array}{c}X^{2} \text { Yatesa }=4,041014 \\
p=0,04441\end{array}$ \\
\hline Don't know & 1 & 1.11 & 3 & 4.62 & $\begin{array}{c}x^{2} \text { Yatesa }=0,7131145 \\
p=0,39841\end{array}$ \\
\hline
\end{tabular}

*Percentage does not add up to 100 due to the possibility of choosing several answers

women gave this answer more often than Belgian women $(\mathrm{p}<0.05)$ (Tab. 2).

The great majority of the respondents had knowledge about the beneficial impact of natural feeding on a child's growth, but there were also those who completely lacked this 
Table 3. Impact of natural feeding on child's growth according to respondents of both nationalities.

\begin{tabular}{|c|c|c|c|c|c|}
\hline \multirow{2}{*}{$\begin{array}{l}\text { Impact of breastfeeding on } \\
\text { child's growth }\end{array}$} & \multicolumn{2}{|c|}{ Poland } & \multicolumn{2}{|c|}{ Belgium } & \multirow{2}{*}{ Statistical analysis } \\
\hline & $\mathrm{n}$ & $\% *$ & $\mathrm{n}$ & $\% *$ & \\
\hline $\begin{array}{l}\text { Causes optimal physical } \\
\text { growth }\end{array}$ & 72 & 80.00 & 25 & 38.46 & $\begin{array}{c}x^{2} \text { Yatesa }=26,063366 \\
p=0.00000\end{array}$ \\
\hline $\begin{array}{l}\text { Has beneficial effect on mental } \\
\text { development }\end{array}$ & 71 & 78.89 & 20 & 30.77 & $\begin{array}{c}x^{2} \text { Yatesa }=34,09280 \\
p=0.00000\end{array}$ \\
\hline Promotes mental development & 62 & 68.89 & 22 & 33.85 & $\begin{array}{c}x^{2} \text { Yatesa }=17,28511 \\
p=0.0003\end{array}$ \\
\hline $\begin{array}{l}\text { Has no effect on child's } \\
\text { development }\end{array}$ & 2 & 2.22 & 14 & 21.54 & $\begin{array}{c}\mathrm{X}^{2} \text { Yatesa }=13,19730 \\
\mathrm{p}=0.00028\end{array}$ \\
\hline $\begin{array}{l}\text { May postpone child's } \\
\text { development }\end{array}$ & 0 & 0.00 & 1 & 1.54 & $\begin{array}{c}x^{2} \text { Yatesa }=0,0268828 \\
p=0.86976\end{array}$ \\
\hline Don't know & 0 & 0.00 & 1 & 1.54 & $\begin{array}{c}x^{2} \text { Yatesa }=4,941822 \\
p=0,02622\end{array}$ \\
\hline
\end{tabular}

* Percentage does not add up to 100 due to the possibility of choosing several answers

knowledge. In this case, the Polish women again had greater knowledge about this than the Belgian women $(\mathrm{p}<0.05)$ (Tab. 3).

A similar percentage of respondents had knowledge about the impact of natural feeding on the child's state of heath, but had a significantly lower knowledge about its impact on the adult's state of health. Polish women also knew more about that than Belgian women ( $\mathrm{p}<0.05)$ (Tab. 4).

Table 4. Impact of natural feeding on child's health state according to respondents of both nationalities.

\begin{tabular}{|c|c|c|c|c|c|}
\hline \multirow{2}{*}{$\begin{array}{l}\text { Impact of breastfeeding on } \\
\text { child's health state }\end{array}$} & \multicolumn{2}{|c|}{ Poland } & \multicolumn{2}{|c|}{ Belgium } & \multirow{2}{*}{ Statistical analysis } \\
\hline & $\mathrm{n}$ & $\% *$ & $\mathrm{n}$ & $\% *$ & \\
\hline $\begin{array}{l}\text { Protects from childhood } \\
\text { diseases. infections. Shortages }\end{array}$ & 71 & 78.89 & 24 & 36.92 & $\begin{array}{c}x^{2} \text { Yatesa }=26,27496 \\
p=0,00000\end{array}$ \\
\hline Prevents allergies & 58 & 64.44 & 28 & 43.08 & $\begin{array}{c}\mathrm{X}^{2} \text { Yatesa }=6,138383 \\
\mathrm{p}=0,01323\end{array}$ \\
\hline Prevents diseases in adulthood & 25 & 27.78 & 16 & 24.62 & $\begin{array}{c}X^{2} \text { Yatesa }=0,0655095 \\
p=0,79799\end{array}$ \\
\hline $\begin{array}{l}\text { Has no impact on child's } \\
\text { health state }\end{array}$ & 2 & 2.22 & 5 & 7.69 & $\begin{array}{c}x^{2} \text { Yatesa }=1.503971 \\
p=0,22006\end{array}$ \\
\hline Don't know & 9 & 10.00 & 19 & 29.23 & $\begin{array}{c}x^{2} \text { Yatesa }=8,175647 \\
p=0,00425\end{array}$ \\
\hline
\end{tabular}

* Percentage does not add up to 100 due to the possibility of choosing several answers

The assumption was made in the study that the sociodemographic variables may affect the knowledge of the respondents about natural feeding. Therefore, 8 variables were adopted: nationality, age, place of residence, education, professional activity, marital status, having children and breastfeeding in the past. Statistical analysis showed that neither marital status nor professional activity or having children varied knowledge on this topic ( $p>0.05$ ). However, nationality, age, education, place of residence and breastfeeding in the past had a significant impact on the women's knowledge $(\mathrm{p}<0.05)$. Polish women who were older, had a better education, living in cities and breastfeeding previously, had a higher level of knowledge (Tab. 5).

The respondents acquired knowledge about natural feeding mainly from the family (56.1\%), from books and popular magazines (48.4\%), the Internet and media (34,2\%), and from friends $(32.9 \%)$, while the smallest number acquired it from a doctor, nurse or midwife (31.0\%). Belgian women
Table 5. Impact of socio-demographic factors on respondents' level of knowledge on natural feeding

\begin{tabular}{|c|c|c|c|c|c|c|}
\hline \multirow{2}{*}{ Variables } & & & \multicolumn{3}{|c|}{ Knowledge level } & \multirow{2}{*}{$\begin{array}{c}\text { Statistical } \\
\text { analysis }\end{array}$} \\
\hline & & & Absence & Incomplete & Sufficient & \\
\hline \multirow{4}{*}{ Nationality } & \multirow{2}{*}{ Polish } & $\mathrm{n}$ & 18 & 53 & 19 & \multirow{4}{*}{$\begin{array}{l}Z=3,176905 \\
\mathbf{p}=\mathbf{0}, \mathbf{0 0 1 4 8 9}\end{array}$} \\
\hline & & $\%$ & 20.00 & 58.89 & 21.11 & \\
\hline & \multirow{2}{*}{ Belgian } & $\mathrm{n}$ & 28 & 33 & 4 & \\
\hline & & $\%$ & 43.08 & 50.77 & 6.15 & \\
\hline \multirow{6}{*}{ Age } & \multirow{2}{*}{$\begin{array}{l}\leq 22 \text { years } \\
\text { old }\end{array}$} & $\mathrm{n}$ & 24 & 27 & 5 & \multirow{6}{*}{$\begin{array}{c}H=8,508584 \\
\mathbf{p}=\mathbf{0 , 0 1 4 2} \\
\mathrm{R}=0,196577 \\
\mathbf{p}=\mathbf{0 , 0 1 4 2 2 6}\end{array}$} \\
\hline & & $\%$ & 42.9 & 48.20 & 8.93 & \\
\hline & $23-26$ & $\mathrm{n}$ & 10 & 31 & 11 & \\
\hline & years old & $\%$ & 19.20 & 59.60 & 21.15 & \\
\hline & \multirow{2}{*}{$\begin{array}{l}\geq 27 \text { years } \\
\text { old }\end{array}$} & $\mathrm{n}$ & 12 & 28 & 7 & \\
\hline & & $\%$ & 25.50 & 59.60 & 14.89 & \\
\hline \multirow{6}{*}{$\begin{array}{l}\text { Education } \\
\text { level }\end{array}$} & \multirow{2}{*}{$\begin{array}{l}\text { Primary/ } \\
\text { vocational }\end{array}$} & $\mathrm{n}$ & 12 & 10 & 0 & \multirow{6}{*}{$\begin{array}{c}H=14.61174 \\
p=0,0007 \\
R=0,301738 \\
p=0,000136\end{array}$} \\
\hline & & $\%$ & 54.55 & 45.45 & 0.00 & \\
\hline & Sorondar & $\mathrm{n}$ & 18 & 38 & 3 & \\
\hline & seconaary & $\%$ & 30.51 & 64.41 & 5.08 & \\
\hline & \multirow{2}{*}{ Higher } & $\mathrm{n}$ & 16 & 38 & 20 & \\
\hline & & $\%$ & 21.62 & 51.35 & 27.03 & \\
\hline \multirow{4}{*}{$\begin{array}{l}\text { Place of } \\
\text { living }\end{array}$} & \multirow{2}{*}{ Urban } & $\mathrm{n}$ & 14 & 44 & 17 & \multirow{4}{*}{$\begin{array}{l}Z=2,703643 \\
\mathbf{p}=\mathbf{0}, \mathbf{0 0 6 8 5 9}\end{array}$} \\
\hline & & $\%$ & 18.67 & 58.67 & 22.67 & \\
\hline & \multirow{2}{*}{ Rural } & $\mathrm{n}$ & 32 & 42 & 6 & \\
\hline & & $\%$ & 40.00 & 52.50 & 7.50 & \\
\hline \multirow{4}{*}{$\begin{array}{l}\text { Breast- } \\
\text { feeding }\end{array}$} & \multirow{2}{*}{ Yes } & $\mathrm{n}$ & 4 & 20 & 5 & \multirow{4}{*}{$\begin{array}{l}Z=2,481450 \\
\mathbf{p}=\mathbf{0}, \mathbf{0 1 3 0 8 5}\end{array}$} \\
\hline & & $\%$ & 13.79 & 68.97 & 17.24 & \\
\hline & \multirow{2}{*}{ No } & $n$ & 6 & 10 & 1 & \\
\hline & & $\%$ & 35.29 & 58.82 & 5.88 & \\
\hline
\end{tabular}

more often than Polish women asked health-care workers for help in this area $(p=0,000)$,

The respondents were asked for a self-assessment of their knowledge about natural feeding. Figure 2 presents the results which indicate that it was slightly higher than the assessment of the authors of the presented study. Belgian women assessed their knowledge better than Polish women $(0=0,009)$.

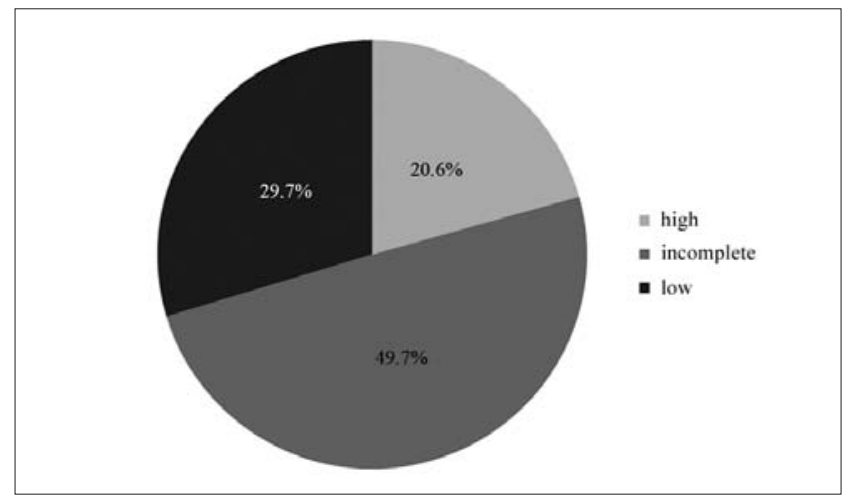

Figure 2. Self-assessment on knowledge about natural feeding by the respondents

More than half of the respondents (58.1\%) admitted that there were gaps in their knowledge about natural feeding that needed filling, 29\% did not see such need, while 12.9\% did not know whether they wanted to know more (Fig. 3). 


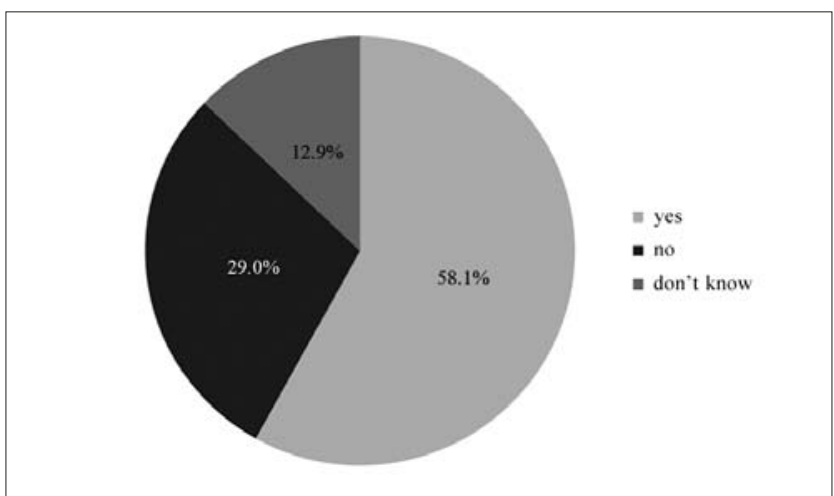

Figure 3. Need for health education in the area of natural feeding among respondents

Polish women showed bigger interest than Belgian women $(\mathrm{p}=0,000)$.

\section{DISCUSSION}

Until the end of of the $19^{\text {th }}$ century, before artificial mixtures were introduced, breastfeeding was the only method that allowed the infant to survive and grow properly. The fast development of civilization and emancipation of women caused natural feeding to fade away - firstly in the highly civilized countries, and then in almost in all societies. During last few years, the actions building awareness about the advantages of natural feeding have gradually stopped this process $[5,6,7,11,18,19]$.

Breastfeeding depends on the willingness and decision of a woman. In order to counteract the move away from natural feeding, the information support must be provided earlier $[18,19,21,22,23,24,25,26]$. The mother's knowledge about lactation is often transferred from generation to generation or often heard from a third party. Birth schools in Poland aim at preparing pregnant women to give birth and the lactation issue is marginal. In recent years, knowledge about breastfeeding has stopped being information passed orally from generation to generation, but has become a sorted and integrated science, medical knowledge based on scientific evidence. In spite of access to knowledge about feeding infants, many mothers have problems with the proper feeding of their children $[15,23]$. Additionally, women do not always decide to breastfeed and sometimes stop before 6 months pass. It can be assumed that if women had greater knowledge in this area, they would not have stopped breastfeeding too early. Due to the high percentage of children fed artificially or breastfed for too short a time, there is a necessity to undertake actions in order to promote breastfeeding. Healthcare workers in particular are obliged to promote natural feeding. The multi-directional promotion of breastfeeding on a countrywide scale is of great significance for making a decision about breastfeeding $[24,27]$. Norway is a good example of this, where in 1968 less than $30 \%$ of mothers breastfed for 12 months, while after promotional campaigns, the percentage reached over $80 \%$ in 1991 [22].

Own studies show that natural feeding still requires promotion and support. Knowledge among respondents varies a lot and is incomplete. Although women often do not know the benefits of natural feeding, most of the respondents were aware that breastfeeding influenced the child's health but do not have complete knowledge on this topic. The respondents also did not have knowledge about the advantages in adult life resulting from breastfeeding. Only a small percentage of respondents (15\%) had bigger knowledge about the benefits of breastfeeding. This might result from the fact that none of the health-care workers had provided such information, which has also been observed by other authors [28, 29, 30].

Own studies show bigger knowledge about breastfeeding among young women in Poland that in Belgium. This may result from the fact that Polish women are attached to tradition, and that the resources for advertising expensive milk substitutes mixtures are much more limited in Poland.

In comparing the presented results with those obtained by Cierpka et al. in 2006 and Gebuza et al. in 2008, it was noticed that the knowledge of women about natural feeding remained on a similar level, differentiated only by age, education, place of residence and previous experience in this area $[28,29,30]$.

Taking into account that in spite of the competences of a doctor, nurse and midwife in informing about feeding infants, the main source of information among women were the media and women's magazines, the recommendation to breast feed should also be published outside the medical universities. Some publications suggest that in order to achieve better effectiveness of such a campaign, examples of diseases that can be potentially avoided thanks to proper infant feeding should also be presented $[4,7,8,9,12,13]$.

However, it is a positive fact that aa significant majority of respondents wanted to breastfeed their child in the future, have already looked for information and believe that it is necessary to find more information. The interest of respondents in health education on this topic was so great that it should be made use of.

\section{CONCLUSIONS}

1. Knowledge of young women about natural feeding varies, it is incomplete and requires complement.

2. The level of knowledge was influenced by: nationality of respondents, their age, place of residence, level of education and breastfeeding in the past. Marital status, professional activity and having children were of no importance. Older women living in Poland who were better educated, living in the cities and had breastfed previously, had significantly greater knowledge about natural feeding. There is a very big need for health education in this area.

\section{REFERENCES}

1. Huang J., Peters K.E., Vaughn M. G., Witko Ch. Breastfeeding and trajctories of children's cognitive development. Developmental Science 2014;17(3):452-461.

2. Tozzi A.E., Bisiachi P., Tarantino V., Chiarotti F., D’elia L., De Meli B. et al. Duration of breastfeeding and neuropsychological development. Development Medicine\&Child Neurology 2012;54:843-848.

3. Szajewska H., Norvath A., Dziechciarz P. Postępy w gastroenterologii i żywieniu dzieci w 2008 roku. Medycyna Praktyczna Pediatria 2009;2:30-43. Development in gastroenterology and feeding children in 2008 .

4. Kowalewska-Kantecka B. Unikalna wartość pokarmu kobiecego dla zdrowia dziecka. Pielęgniarka i Położna 2006;6:4-5. Unique value of human milk for child's health.

5. Kramer M.S., Aboud F., Mirnova E. Promotion of Breastfeeding Intervention Trial (PROBIT) Study Group. Breastfeeding and child 
cognitive development: new evidence from a large randomized trial. Arch Gen Psychiatry 2008;65:578-584.

6. Muszyńska A., Pokorna-Kalwak D., Mastalerz-Migas A., Steciwko A. Sposoby żywienia niemowląt-karmienie naturalne czy sztuczne? Family Medicine\&Primary Care Review 2010;12(3):744-746. Methods of feeding the infants - natural or artificial?

7. Krauss H., Ignaś I., Sosnowski P., Marcinkowski J., Śliwińska I., Klincewicz B. Karmienie naturalne a zdrowie dziecka. Pediatria Współczesna. Gastroenterologia, Hepatologia i Żywienie Dziecka 2009;11(3):145-152. Natural feeding and child's health.

8. Oddy W. The long-term effects of breast-feeding on asthma and atopic disease. Adv Exp Med Biol 2009;639:237-251.

9. Greer F.R., Sicherer S.H., Burks A.W. American Academy of Pediatrics Committee on Nutrition; American Academy of Pediatrics Section on Allergy and Immunology: Effects of early nutritional interventions on the development of atopic disease in infants and children: the role of maternal dietary restriction, breastfeeding, timing of introduction of complementary foods, and hydrolyzed formulas. Pediatrics 2008;121:183-191.

10. Chmielewska A., Szajewska H. Żywienie niemowląt-aktualne wytyczne. Lekarz 2012;2:22-27. Feeding infants - the current recommendations.

11. Ong K.K, Forouhi N. Communicating the benefits of breast feeding. Arch Dis In Child 2007;92:471-472.

12. Tymecka I., Rugała A. Karmienie naturalne chorych niemowląt-teoria a praktyka. W: Materiały z Międzynarodowej Konferencji Naukowej: Pielęgniarstwo a jakość życia człowieka. 2000.09.7-8.; Kraków:106-110 Natural feeding of sick infants - theory and practice.

13. Rugała A., Tymecka I. Znaczenie karmienia naturalnego dla niemowląt chorych i niepełnosprawnych. W: Materiały z Ogólnopolskiej Konferencji Naukowej: Pielęgniarka, położna w promocji zdrowia. 1999.12.15; Warszawa:1-6. Meaning of natural feeding for sick and disabled infants.

14. Dzwonkowska S. Karmienie niemowląt. Pielęgniarka i Położna 2011;10:10. Feeding the infants.

15. Kaminowska M., Szczepański M., Andryszuk B., Kamionowski G., Milewski R. Analiza wpływu czynników okołoporodowych oraz wiedzy matek z zakresu laktacji na sposób żywienia niemowląt. Pediatria Polska 2010;85(1):25-34. Analysis of the impact of perinatal factors and mothers' knowledge in the field of lactation on infant nutrition.

16. Gartner L., Morton J., Lawrence R., Naylor A., O'Hare D., Shandler R. et al. American Academy Pediatrics Section on Breastfeeding and the use of human milk. Pediatrics 2005;115:496-506.

17. Riordan J. Breastfeeding the Preterm Infant. Breastfeeding and Human Lactation. Jones\&Bartlett Publishers, USA 2004:367-407.
18. Van Acker F., Bekker E. A functional assessment of the impact of advantages and disadvantages on breastfeeding attitude. International Journal of Methodology and Experimental Psychology 2012;33(3):533545.

19. Frochlich J., Boivin M., Rice D., Mc Graw K., Muson E., Corcoran $\mathrm{K}$. et al. Influencing university students' knowledge and attitudes toward breastfeeding. Journal of Nutrition Educatin and Behavior 2013;45(3);282-284

20. Niemierko B. Pomiar wyników kształcenia. Wydawnictwa Szkolne i Pedagogiczne, 2004. Measurement of learning results.

21. Rakuś-Kwiatosz A., Frańczak P., Pac-Kożuchowska E. Ocena sposobu żywienia niemowląt w świetle aktualnych zaleceń. Czynniki Ryzyka 2011;1:18-27. Assessment of infant nutrition method in the light of current recommendations.

22. Laskowska J., Książyk J. Aktualne wytyczne dotyczące karmienia piersią. Pediatr Med. Rodz 2011;7(2):110-114. Current recommendations regarding breastfeeding.

23. Książyk J., Janiec A. Wybrane zagadnienia dotyczące żywienia dzieci. Medycyna Praktyczna Pediatria 2009;6:-18. Selected issues related to children nutrition.

24. Sikorski J., Renfrew M.J., Pindora S. Ocena skuteczności różnych metod promocji karmienia piersią-przegląd systematyczny. Medycyna Praktyczna Pediatria 2005;1:17-18. Assessment of effectiveness of different methods of promoting breastfeeding - systematic review.

25. Grummer-Strawn L., Shealy K. Progress in protecting, promoting and supporting breastfeeding: 1984-2009. Breastfeed Med 2009;4:31-39. Babczyńska-Gratze M.,

26. Banaszkiewicz A., Baranowska B. Karmienie piersią w teorii i w praktyce. Medycyna Praktyczna Pediatria 2012;31:413. Breastfeeding in theory and practice.

27. Mikiel-Kostyra K. Ocena skuteczności różnych metod promocji karmienia piersią-przegląd systematyczny. Medycyna Praktyczna Pediatria 2006 wyd. specj.;1:25-28. Assessment of effectiveness of different methods of promoting breastfeeding - systematic review.

28. Majczakowska W., Wożniak I., Zagórski J. Karmienie naturalne niemowląt-problemy i przyczyny niepowodzeń. Medycyna Ogólna 2005;11:156-166. Natural feeding of infants - problems and reasons of failures.

29. Cierpka A., Żuralska L., Olszewski J., Gaworska-Krzemińska A. Wiedza położnic na temat karmienia piersią. Prob Pielęg 2007;2(3):178. Knowledge of midwives on breastfeeding.

30. Gebuza G., Gierszewska M., Każmierczak M., Michalska E., Kotzbach R. Przygotowanie kobiet do karmienia piersią. Prob Pielęg 2010:18(4):406412. Preparing women for breastfeeding. 